\title{
The Influence of Sports Celebrity Credibility on Purchase Intention: The Moderating Effect of Gender and Consumer Sports-Involvement
}

\author{
Natalie Bragança Düsenberg ${ }^{\dagger}$ \\ Comitê Organizador dos Jogos Olímpicos e Paralímpicos \\ Victor Manoel Cunha de Almeida ${ }^{\Omega}$ \\ Universidade Federal do Rio de Janeiro (UFRJ/COPPEAD) \\ João Guilherme Barbosa de Amorim \\ McKinsey \& Company
}

\begin{abstract}
This study investigates the effects of sport's celebrity endorsement on purchase intention. More specifically, this study seeks to (1) identify the extent to which the sports celebrity's credibility influences consumer purchase intention; (2) the extent to which gender moderates the effect of sports celebrity endorsement on purchase intention; and (3) to what extent consumer sports-involvement moderates the effect of a sports celebrity endorsement on purchase intention. One famous Brazilian soccer player and four product categories were used as stimuli. The research method used was a survey, which has included 1,025 respondents. Data analysis was performed using exploratory factor analysis (EFA) and confirmatory factor analysis (CFA). Structural equation modeling (SEM), using the ADF technique, was applied to test the substantive hypotheses. To test the hypotheses of the moderating effect of gender and consumer sports-involvement, the research used the multigroup analysis technique. The empirical results support the relationship between a sport celebrity's endorsement and purchase intention. The moderating effects of gender and sports-involvement were also empirically supported, but only partially.
\end{abstract}

Keywords: Sport celebrity; Source credibility; Endorsement; Sport Involvement.

Received in 03/20/2016; revised in 05/29/2016; accepted in 06/28/2016; divulgued in 11/21/2016

*Author for correspondence:

$\dagger$. Master in Administration Institution: Comitê Organizador dos Jogos Olímpicos e Paralímpicos Address: Rua Pascoal Lemme, 355

Ilha do Fundão, Rio de Janeiro - RJ Brazil - CEP 21941-918

E-mail: natidusenberg@gmail.com
$\Omega$. Doctor in Administration Institution: Universidade Federal do Rio de Janeiro (UFRJ/COPPEAD) Address: Rua Pascoal Lemme, 355 Ilha do Fundão, Rio de Janeiro - RJ Brazil - CEP 21941-918 E-mail: valmeida@coppead.ufrj.br

\footnotetext{
*. Master in Administration Institution: McKinsey \& Company Address: Rua Pascoal Lemme, 355 Ilha do Fundão, Rio de Janeiro - RJ Brazil - CEP 21941-918 E-mail: jgbamorim@yahoo.com.br
} 


\section{INTRODUCTION}

$\mathrm{I}$

n today's global society, marketing messages are competing for attention because of the multiple and complex myriad of messages being communicated. Consumers are processing more sport marketing messages about products, services and technologies. In this context, the task of sport marketers is to focus on the best strategies to reach consumers efficiently, targeting the appropriate segments with the most appealing messages and engaging with audiences in a dynamic process (RATTEN, 2016).

As more people around the world use the internet and related communication technologies to watch live sport events, there has been a rise in athletes been seen as global celebrities, what makes their images relate to more positive attributes, which include symbolic and functional benefits (RATTEN, 2015). Sports sponsorship, which aims to establish a relations with customers through the sponsored properties, attained US\$ 35 billion in 2011 and was expected grow at an average rate of 5.3\% per year worldwide until 2015, totaling US\$ 45 billion (PWC, 2011). Celebrity endorsement, i.e. the use of celebrities to promote products in advertisements (SCHIFFMAN; KANUK, 1997), have become an increasingly important part of the marketing ecosystem (MILLER; LACZNIAK, 2011) and an imperative component of sports marketing for many corporations (YU, 2005).

The actual context of internalization of the global economy has meant that many sport marketers now look to the global market instead of one region in their market efforts (RATTEN, 2011), making sport celebrities more valuable as their image become globally famous. The 100 highest-paid athletes in the world earned a collective \$741 million in endorsement deals in 2014 (BADENHAUSEN, 2014). Athletes Roger Federer, Tiger Woods and Lebron James have received around 58, 50 and 48 million dollars in endorsement deals in 2015, respectively (FORBES, 2015). Two of the highest-paid Brazilian athletes are Neymar Jr., who signed with Nike the 10th biggest athlete endorsement deal in sports history, earning \$105 million over a 11 years deal (TOTAL SPORTEK, 2016), and Ricardo Izecson dos Santos Leite, known as Kaká, who served as stimuli for this study and received $\$ 19.3$ million in 2015, being 5.5 million in endorsement deals (ABC NEWS, 2015).

Some authors investigated consumer sports involvement (DICKERSON; GENTRY, 1983; KO; KIM; CLAUSSEN; HEE, 2008; SHANK; BEASLEY, 1998) and the influence of the endorser's credibility on consumers involved with the sport (SHUART, 2007). However, several authors have recommended further research on celebrity endorsement (CARNEIRO, 2002; GOLDSMITH; LAFFERTY; NEWELL, 2000; OHANIAN, 1990; PORNPITAKPAN, 2003), since there is still little research on the impact of the use of celebrities for product endorsements (SENO; LUKAS, 2007). Specifically, the inclusion of behavioral variables such as purchase intention has been recommended for future studies (CARNEIRO, 2002). 
This is precisely the literature gap that this study intends to address. This study investigates the extent to which sports celebrity endorsements are capable of influencing consumer purchase intention. More specifically, this study seeks to (1) identify the extent to which the sports celebrity's credibility is capable of influencing consumer purchase intention; (2) the extent to which gender is capable of moderating the effect of a sports celebrity endorsement in purchase intention; and (3) to what extent consumer sports-involvement is capable of moderating the effect of a sports celebrity endorsement on purchase intention.

\section{LITERATURE REVIEW}

\section{Global Sports Celebrities}

For a large part of the population, "celebrities represent an idealization of life that most people imagine that they would love to live" (SCHIFFMAN; KANUK, 1997, p. 331). Celebrities are a part of the pop culture consumed by the mass market, representing products as well as serving as inspiration for marketing professionals (SOLOMON, 2007). Celebrities can be sports athletes, actors, musicians, comedians or any kind of artist, as well as fictional characters, CEOs and high-ranking business professionals (SCHIFFMAN; KANUK, 1997).

A growing number of athletes have become celebrities and television stars, to the point that they are seen as human brands, meaning that an athlete's image may be associated with different attributes, which may have a significant effect on team and sponsor evaluation and on consumer's behaviors (CARLSON; DONOVAN, 2013). Consequently, strategic branding based on marketing theory is now truly needed for athletes and sports marketers, that need to have a deeper understanding of which factors make strong athlete brands (ARAI; KO; ROSS, 2013).

During the $21^{\text {st }}$ century, the world of sports became so thoroughly marketed and mediatized that it started to appear as common property, circulating within and between regions with such apparent ease as to suggest that even the most diverse societal formations can somehow be united through some form of shared sporting practice (ROWE; GILMOUR, 2010). In this context, as more people around the world use the internet and related communication technologies to watch live sport events, there has been a rise in athletes being seen as global celebrities, making their images related to more positive attributes, which include symbolic and functional benefits (RATTEN, 2015).

\section{Celebrity Endorsement}

Endorsements consist in the use of a celebrity's name to promote products and services in which they may or may not be experts (SCHIFFMAN; KANUK, 1997). The celebrity endorser can be defined "as any individual who enjoys public recognition and who uses this recognition on behalf of a consumer good by appearing with it in an advertising" (MCCRAKEN, 1989, p. 310). 
By purchasing a product, a consumer can make statements about his lifestyle and the person that he is or would like to be. In that sense, the symbolic benefits that products and brands offer to consumers represent one incentive for such consumption (SOLOMON, 2007).

The use of celebrity endorsements can also be an effective way of creating and changing brand associations (CHOI; RIFON, 2007), and therefore generating value for both product and brand levels (SENO; LUKAS, 2007). However, studies have shown that celebrity endorsement does not build brand equity directly; rather it influences the endorsed brand's credibility, subsequently leading to an improvement in brand equity (SPRY; PAPPU; CORNWELL, 2011), which then results in a positive pay-off in brand-level sales and increases the firm's stock returns (ELBERSE; VERLEUN, 2012).

\section{Sports Celebrity Endorsement}

Among celebrities, athletes are highly valued for advertising purposes (CHOI; RIFON, 2007). The successful and winning athletes are considered the best endorsers, because their talent represents to customers "high quality, high performance and guarantee of success." (MELO NETO, 1995, p. 165-166). The athlete's performance is an important aspect to consider, because it affects the rewards obtained by the endorsed firm over time: sales and stock returns increase noticeably with each major championship won by the endorser (ELBERSE; VERLEUN, 2012).

By relating their products to athletes, sponsors seek to transfer perceptions of these athletes to their brands (XING; CHALIP, 2006). Thus, endorser's credibility is an important element to consider when aiming to enhance consumers' attitude toward the advertisement and the brand, and purchase intention (LEE; KOO, 2015). A study about the effect of the use of the golfer Tiger Woods has determined that from 2000 to 2010, the Nike golf ball division got an additional profit of \$103 million from Tiger Woods' endorsement effect. Moreover, having Tiger Woods' endorsement led to a price premium of roughly 2.5\% (CHUNG; DERDENGER; SRINIVASAN, 2013).

Consumers' positive beliefs toward an endorser are expected to transfer to the endorsed brand based upon their cognitive associations (KOO; RUIHLEY; DITTMORE, 2012). According to the source credibility model, consumers tend to be influenced when they perceive the source of information as credible, resulting in more positive attitudes as well as more behavioral compliance (OHANIAN, 1991). Koo et al. (2012), Lee and Koo (2015), Ohanian (1991) and Pornpitakpan (2003) demonstrated empirically that the credibility of the endorser has a positive correlation with consumer purchase intention. The credibility of endorsers can also influence consumer attitudes towards the advertisement and the brand (AMOS; HOLMES; STRUTTON, 2008; GOLDSMITH; LAFFERTY; NEWELL, 2000), the attitude toward the ad (KOO et al., 2012) and the endorsed brand customer-based brand equity (SPRY; PAPU; CORNWELL, 2011). 
Based on the arguments above, the following hypothesis is proposed:

Hypothesis H1: The greater the credibility of the sports celebrity, the greater the influence of the endorsement on purchase intention.

Furthermore, considering that, according to Ohanian (1990), there are three dimensions that make up endorser's credibility, it can be hypothesized that: (H1a) the greater the attractiveness of the sports celebrity, the greater the influence of the endorsement on purchase intention; (H1b) the greater the expertise of the sports celebrity, the greater the influence of the endorsement on purchase intention; and (H1c) the greater the trustworthiness of the sports celebrity, the greater the influence of the endorsement on purchase intention.

\section{Consumer gender}

Men and women process cognitive information differently. The "selectivity model", which has already been applied to marketing advertising research, states that men are "selective processors", which often rely on a subset of highly available and salient stimuli in place of detailed mental development of a particular message, while women try to assimilate all available information before producing an evaluation of the message received (MEYERS-LEVY; MAHESWARAN, 1991). In practical terms, gender is considered one of the most determinant individual factors that determine change of attitude regarding the effects of communication messages (HAWKINGS et al., 2007).

In the sports marketing context, some studies have shown that men and women perceive and process information in different ways: gender influences the perceived quality of the product that, in turn, influences the consumer's purchase intention (LEE; KIM; KO; SAGAS, 2011). Men seem to be more likely to use the sponsoring brand of a sports event (BENNETT et al., 2009) and are more influenced to buy products endorsed by sports celebrities than women (SHUART, 2007). However, female consumers spread more positive word-of-mouth about a brand or product endorsed by their favorite athletes (BUSH; MARTIN; BUSH, 2004). There is also evidence that that female sports fans attach more importance to a player's personality and behavior while male fans seem to focus on experience and skills of the endorser athletes (HOEGELE; SCHIMDT; TORGLER, 2015). Lastly, gender affects the perceived expertise of the endorser and the consumer's purchase intention (FINK et al., 2012).

Based on the arguments above, the following hypothesis is proposed:

Hypothesis H2: The consumer's gender exerts a moderating effect on the influence of the sports celebrity's endorsement credibility on purchase intention.

Furthermore, considering that there are three dimensions that make up endorser's credibility, it can be hypothesized that consumer gender exerts a moderating effect: (H2a) on the influence of the sports celebrity's attractiveness on purchase intention; $(\mathrm{H} 2 \mathrm{~b})$ on the influence of the sports 
celebrity's expertise on purchase intention; and (H2c) on the influence of sports celebrity's trustworthiness on purchase intention.

\section{Consumer Sports Involvement}

The phenomenon of fan involvement provides a powerful explanation of social behavior (MEENAGHAN, 2001). Involvement can be defined as the relevance that a person perceives that an object has on their needs, values and interests (BEATON; FUNK; RIDINGER; JORDAN, 2011). Specifically in the sports context, involvement would describe the level that a consumer values or believes that sports are relevant and important to their lives and lifestyles (BENNETT et al., 2009). There are three basic forms of involvement with sports: behavioral, cognitive and affective (MULIN; HARDY; SUTTON, 2004). Consumer decisions are based on a combination of cognitive and affective dimensions. In general, affection refers to emotion or feeling. Whereas the cognitive dimension refers to the processing, evaluation and planning of actions (SAUERBRONN; BARROS, 2005). The involvement with sports generates symbolic and hedonistic values (BEATON et al., 2011).

The sports involvement can also be defined as a deep and personal connection with the sport. It is a passion for the sport, and not for a specific team, which differentiates the sports involvement from the affinity for a team (GWINNER; SWANSON, 2003). The connection between an individual and a sport is determined by the complexity and power of the mental associations of the former in relation to the latter (FUNK; JAMES, 2001). Additionally, the sports involvement is related to an individual's assessment of the importance of their participation in activities related to a particular sport in their lives (BEATON et al., 2011). This being one of the three dimensions that affects consumer purchase intention for the products of a given sport's sponsor (MEENAGHAN, 2001).

Sports involvement is a good indicator for predicting sports-related behavior. People with high sports involvement spend more time watching sports programs on television, reading about sports and attend to more sporting events than people with low sports involvement (SHANK; BEASLEY, 1998). Highly involved people also tend to have positive attitudes towards advertisements related to that sport (PYUNG; JAMES, 2011) and show a greater purchase intention for the products of that specific sports' sponsors (DEES; BENNETT; VILLEGAS, 2008). Finally, the greater a person's involvement with sports, the greater the likelihood that they will purchase products endorsed by athletes (SHUART, 2007).

Based on the arguments above, the following hypothesis is proposed:

Hypothesis H3: Sport-specific consumer involvement has a moderating effect on the influence of the sports celebrity's endorsement credibility on purchase intention. 
Furthermore, considering that there are three dimensions that make up endorser's credibility, it can be hypothesized that the consumer's involvement with the celebrity's sport exerts a moderating effect: (H3a) on the influence of the sports celebrity's attractiveness on purchase intention; (H3b) on the influence of sports celebrity's expertise on purchase intention; and (H3c) on the influence of sports celebrity's trustworthiness on purchase intention.

\section{Conceptual Model}

To address the main purpose of this study, a conceptual model was developed (see Figure 1), inspired by the model originally proposed and tested by Ohanian (1990). The approach proposed by the author to examine the credibility of the endorser has been adapted and extended to include the moderating effects of gender and consumer's sport involvement.

\section{METHODS}

\section{Sample and Data Collection}

This study uses a non-probability sample, selected using quotas (MALHOTRA, 2006), composed of undergraduate students from public and private higher education institutions (HEI) in the State of Rio de Janeiro, Brazil. The gender of the respondent and the type of product were

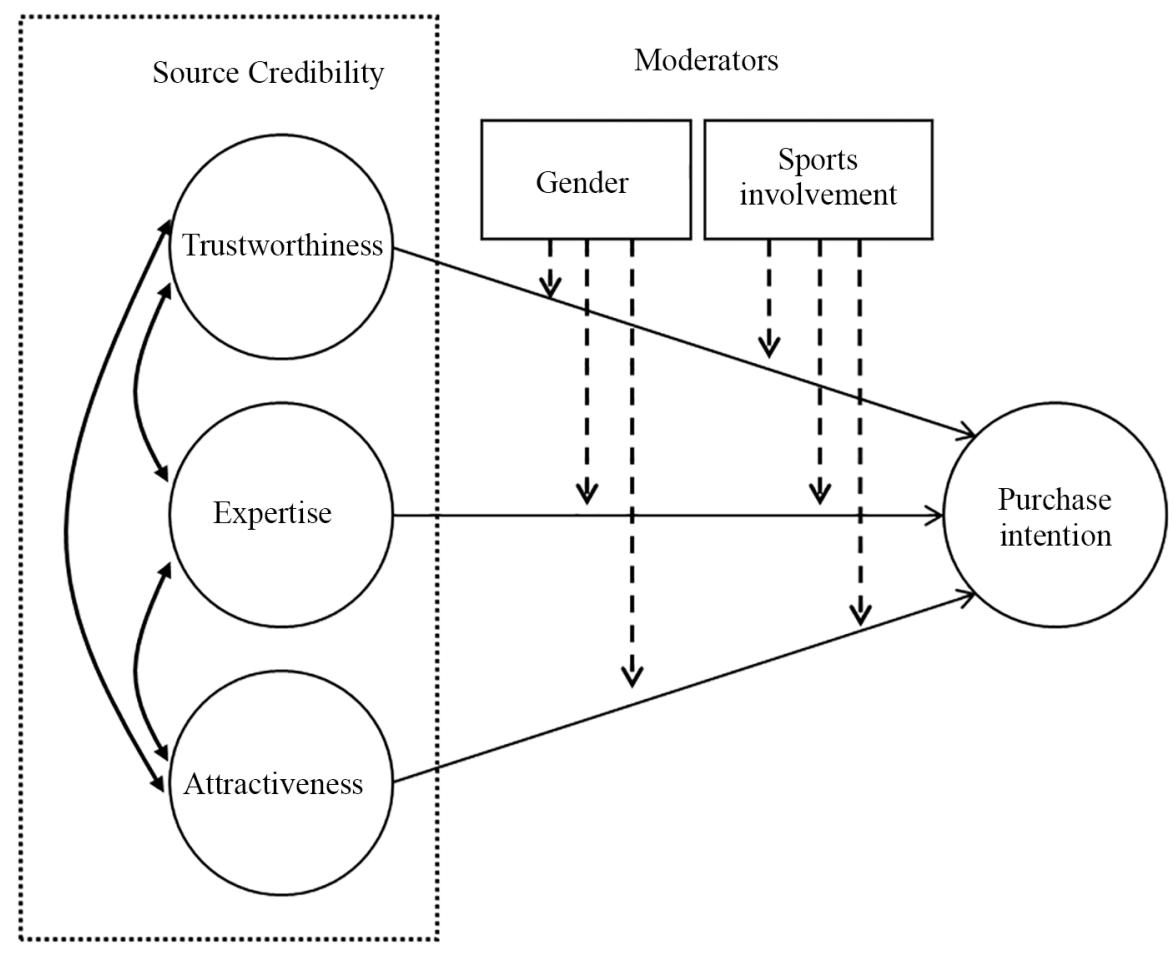

Figure 1. Conceptual Model 
the control variables for the quota sampling. The data was collected through a self-administrated survey under the supervision of researchers.

The sports celebrity chosen for this study was Ricardo Izecson dos Santos Leite, known as Kaká. The choice stems from the respondents' familiarity with this player, since he was voted best player in the world by FIFA in 2007. Four product categories were selected for the study: tennis shoes, cell phones, sports drinks and soda. These categories were used in their entirety or partially in previous research, more specifically in the Garland and Ferkins (2003) and Lee and Thorson (2008) and Shuart (2007) studies.

\section{Independent variables, moderators and dependent variables}

The dependent variable is the Purchase Intention, measured through three variables proposed by Ohanian (1991), which capture the most influential effects on purchase intentions, brand attitudes and attitudes towards the advertisement (AMOS et al., 2008). The independent variables are the three endorser credibility dimensions: Trustworthiness, Expertise and Attractiveness. Ohanian's (1990) Source Credibility scale was used to operationalize this group of variables. The respondent's gender, as well as their sports involvement, are the moderating variables in this study. To measure sports involvement, Shank and Beasley's (1998) Sports Involvement Inventory was used. A binary variable (low involvement - high involvement) was created using the median of the overall scale score as the cutoff. The scales were translated to Portuguese using the translation and back-translation process. Two pre-tests were conducted, using respondents of different economic and educational levels and professions. The respondents were requested to be honest about any doubts or criticism that could arise about the questions of the questionnaire. Care was taken in order to carefully evaluate and interpret the gestures and facial expressions of the respondents.

\section{Analysis Procedures}

The data collected was analyzed using descriptive analysis and exploratory factor analysis (EFA), performed with SPSS software; and confirmatory factor analysis (CFA) and structural equation modeling (SEM), using AMOS software. During the descriptive analysis process, incomplete surveys were eliminated from the sample and the presence of outliers was investigated. Several EFA procedures were used to validate the scales. The significance of load factors was evaluated using the statistical power as the criterion (HAIR et al., 2006).

The reliability of the constructs was evaluated using Cronbach's $\alpha$, item-to-total correlation and inter-item correlation. The correlation between the items on the scale (ordinal variables) was measured using Spearman's rank correlation coefficient (BEARDEN; NETMEYER, 1999; HAIR 
et al., 2006). Additionally, the convergent and discriminant validity of each scale's constructs were evaluated, respectively using the correlations between the component variables of each construct and the correlations between the variables belonging to the different constructs.

To validate the Source Credibility (SC), a CFA was performed. The analysis of the measurement model was conducted using the goodness-of-fit indicators. The convergent validity was analyzed by testing the load factors, the variance extracted and the reliability (HAIR et al., 2006). The discriminant validity of the constructs was analyzed using common variance. The estimated variance must be greater than the square of the correlation to test for discriminant validity (FORNELL; LARCKER, 1981).

Structural equation modeling (SEM) was used to test the hypotheses. Despite the maximum likelihood estimation (MLE) method being the most commonly used technique, this study used the asymptotically distribution free (ADF) method, because it is insensitive to non-normality of the data. The lack of normality in the variables of the present study was established using the Kolmorov-Smirnov test. As this study features a large sample size $(\mathrm{N}=1025)$, including the subsamples ( $\mathrm{N}>500)$, ADF was chosen to test the model (HAIR et al., 2006).

The hypotheses H1a to H1c, respectively concerning the influence of each of the dimensions of the endorser's credibility on consumer purchase intention were tested through individual analysis of the significance of the coefficients of the correlations between latent variables that make up the endorser's credibility construct and the purchase intention construct.

For the testing of hypotheses H2 and H3, the SEM Multiple Group Analysis was used. According to Kline (2005), the easiest way to check for the moderating effect involves testing the same model for each of the different samples and then comparing the non-standardized coefficients. The author suggests that the moderator be tested for by specifying restrictions for equality between groups (cross-group equality constraints). The constrained fit model must be compared with the free fit model, using the $\Delta \chi^{2}$ statistic.

\section{RESULTS}

Altogether, 1,122 questionnaires were collected. Of these, 97 were discarded due to inadequate replies, incompletion or to the age of the respondent (17 to 30 years was the filter used). As a result, 1,025 questionnaires (91.4\%) were considered valid. The average age of respondents was 21.4 years. The survey was conducted based on quota sampling, for this reason the number of respondents by gender and by product type was similar. Of the 1,025 respondents, $525(51.2 \%)$ were female and $500(48.8 \%)$ were male. 


\section{Endorser Credibility}

To validate the Source Credibility (SC) scale, a Confirmatory Factor Analysis (CFA) was performed. Goodness-of-fit indicators originally specified did not show adequate values for this study's sample. The $\chi^{2}$ had a high value $(508.126$ and $p$ value $<0.05)$. The GFI $(0.836)$ and CFI (0.754) had values below the recommended threshold. The RMSEA(0.069) and the PCLOSE (0.000) also had inadequate values, indicating the lack of a good fit for the model. It was decided, therefore, to purify the scale. The purification process was conducted in a systematic manner, eliminating one variable at a time, noting the contribution of each item to the corresponding construct. In this way, some items were removed from the scale, because they presented one or more standardized residual values above the 2.58 limit (PERIN, 2001). Additionally, some items were eliminated because they showed high covariance with several items from other constructs on the scale. The re-specified model included nine items, three for each of the scale's constructs. According to Hair et al. (2006), there should be a minimum of 3 items per construct. Table 1 presents the goodness-of-fit indicators for the re-specified model compared with the indicators for the original model. All the indicators provide support for the re-specified model's good fit.

The convergent validity was analyzed through examination of the load factors (coefficients) of the variance extracted and the validity. The load factors for trustworthiness, expertise and attractiveness respectively vary from 0.845 to 0.921 ; from 0.674 to 0.939 and 0.831 to 0.906 , indicating adequate convergent validity. The variance extracted from the trustworthiness, expertise and attractiveness constructs showed values equal to $77.6 \%, 72.9 \%$ and $75.6 \%$ respectively. The validity of the expertise, trustworthiness and attractiveness constructs presented values of 0.863 , 0.778 and 0.744 , demonstrating good validity (see Table 2). In the present study, the variance extracted was greater than the estimate of the squared correlation for comparisons between trustworthiness and attractiveness $(0.776>0.455)$ and between expertise and attractiveness $(0.729>0.437)$. This was not true for the comparison between trustworthiness and expertise $(0.729$ $<0.755)$. Therefore these results partially support the discriminant validity of the scale. Finally, it was found that the signs and the significance of the coefficients obtained in this study support the literature's theoretical relationships, suggesting the scale has nomological validity.

Table 1. Measurement Model Overall Fit Statistics

\begin{tabular}{lccccccc}
\hline Overall Fit Statistics & $\chi^{2}$ & $\boldsymbol{p}$-value & $\boldsymbol{\chi}^{\mathbf{2} / \mathbf{d f}}$ & GFI & CFI & RMSEA & PCLOSE \\
\hline 15 items model & 508.126 & 0.000 & 5.841 & 0.836 & 0.754 & 0.069 & 0.000 \\
9 items model & 21.262 & 0.623 & 0.886 & 0.990 & 1.000 & 0.000 & 1.000 \\
Suggested Parameters & & $>0.05$ & $<3.0$ & $>0.9$ & $>0.9$ & $<0.05$ & $>0.5$ \\
\hline
\end{tabular}


Table 2. Reliability and Validity of Measurement Model

\begin{tabular}{lcccc}
\hline & & \multicolumn{3}{c}{ Source Credibility Scale } \\
\cline { 3 - 5 } & & Trustworthiness & Expertise & Attractiveness \\
\hline Item & Semantic Anchors & $\mathrm{CR}=0.863$ & $\mathrm{CR}=0.778$ & $\mathrm{CR}=0.744$ \\
Kaka2i & Honest - dishonest & 0.875 & & \\
Kaka3i & Reliable - unreliable & 0.921 & & \\
Kaka4i & Sincere - insincere & 0.845 & 0.674 & \\
Kaka7i & Experienced - inexperienced & & 0.923 & \\
Kaka9i & Qualified - unqualified & & 0.939 & \\
Kaka10i & Skilled - unskilled & & & 0.906 \\
Kaka11i & Attractive - unattractive & & & 0.869 \\
Kaka13i & Handsome - ugly & & & 0.831 \\
Kaka15i & Sexy - not sexy & & 0.869 & 0.675 \\
\hline Trustworthiness & & 0.776 & 0.729 & 0.661 \\
Expertise & & 0.755 & 0.437 & 0.756 \\
Attractiveness & & 0.455 & &
\end{tabular}

Note: Numbers in bold on diagonal denote the average variance extracted (AVE). Numbers below diagonal denote the squared correlations. Numbers above diagonal denote the correlations.

\section{Purchase Intention}

The Purchase Intention scale was tested through an EFA, using the principal components method. Using Eigenvalue $>1$ as a criterion, a single factor $(\mathrm{KMO}=0.615)$ was extracted, demonstrating the unidimensionality of the construct. The variance extracted was $56.2 \%$. The load factors for the three variables were $0.459,0.855$ and 0.863 . The elimination of a variable could increase the variance extracted, however we decided to keep it to not break the rule of a minimum of three items per construct.

\section{Hypotheses Concerning the Credibility of the Endorser and Purchase Intention}

To test Hypothesis 1, the structural model was specified with the three sports celebrity credibility constructs co-varying and all influencing purchase intention. Table 3 shows the adequacy of all goodness-of-fit indicators for the structural model.

Table 3. Structural Model Overall Fit Statistics

\begin{tabular}{lccccccc}
\hline Overall Fit Statistics & $\boldsymbol{\chi}^{2}$ & $\boldsymbol{p}$-value & $\boldsymbol{\chi}^{2} / \mathbf{d f}$ & GFI & CFI & RMSEA & PCLOSE \\
\hline structural model & 66.448 & 0.04 & 1.384 & 0.979 & 0.988 & 0.019 & 1 \\
suggested parameters & & $>0.05$ & $<3.0$ & $>0.9$ & $>0.9$ & $<0.05$ & $>0.5$ \\
\hline
\end{tabular}


The estimates and significance of the standardized coefficients of each dimension of the sports celebrity's credibility in relation to purchase intention was then analyzed. The t-test was significant for all paths ( $p$ value $<0.05$ ), empirically supporting Hypothesis 1 , as well as hypotheses $1 \mathrm{a}, 1 \mathrm{~b}$ and 1c. By comparing the standardized coefficients, it was found that trustworthiness is the dimension of sports celebrity credibility with the greatest influence on purchase intention (0.196), followed by expertise (0.193) and attractiveness (0.079).

\section{Hypotheses Concerning Gender}

To test Hypothesis 2, cross-validation and invariance tests were performed on the model for gender. The loose cross-validation analysis showed that the values of the goodness-of-fit indicators GFI, CFI and RMSEA are similar for the male group and for the female group, suggesting a good fit of the model for both groups. The male group presented an adequate $\chi^{2}$ (51.9 and $p 0.05>$ value), as did the female group (58.1 and $p$ value $0.05>$ ). The results made the cross-validation criterion acceptable, since the measurement model seems valid in both samples. In sequence, the equivalence of the factorial structure was verified. As expected, the $\chi^{2}$ had a value equal to the sum of the $\chi^{2}$ from the male and female group, as did the number of degrees of freedom (df). It can be observed that the indicators GFI (0.969), CFI (0.990) and RMSEA (0.012) demonstrate a good fit for the measurement model. The $\chi^{2}(110.0)$ was statistically significant ( $p$ value $>0.05$ ). Therefore, these results support the equivalence of the factorial structure, indicating that the structure of the measurement model is suitable for both groups. The equivalence of the groups' factor loading was thus verified. Despite the results of the GFI (0.964), CFI (0.984) and RMSEA (0.150) apparently supporting the equivalence of the factor loading, the difference in $\chi^{2}$ between the models had a $p$ value $<0.05$, negating support for the equivalence of the factor loading between groups. As the results do not support the equivalence of the load factors, the steps for verifying the equivalence of the factor covariance and the equivalence of the error variance could not be supported.

Once the equivalence of the factorial structure was supported, Hypothesis 2 was tested using SEM Multiple Group Analysis. By comparing the models, support for the existence of gender's moderating effect on the influence of a sports celebrity's endorsement credibility on purchase intention was found. The $\Delta \chi^{2}$ in the model's fit had a value of 9.425 (119.462-110.037), which is greater than the critical value of the Chi-square statistic for 3 degrees of freedom (7.815). In this way, the results provide empirical support for Hypothesis 2 that gender moderates the influence of the sports celebrity's endorsement credibility on purchase intention.

Having confirmed the moderator effect of the variable, the specific effect on each of the model's dimensions was tested. Again, three models were specified, and in all models all paths (relations between the three dimensions of the endorser's credibility and the purchase intention) 
were restricted, except for the path being studied. The fit of each of these models was then compared with the fit of the model in which all paths were restricted. For expertise, the $\Delta \chi^{2}$ had a value of 0.005 , below the critical value for 1 degree of freedom (3.841). In fact, the non-standardized coefficients for the male and female groups had very close values, equal to 0.200 ( $p$ value $<0.05$ ) and 0.195 ( $p$ value $<0.05$ ) respectively, denying support for the moderator effect on this relationship. However, for trustworthiness, the $\Delta \chi^{2}$ had a value equal to 5.062, above the critical value of 3.841 , thus supporting hypothesis $\mathrm{H} 2 \mathrm{~b}$, related to the existence of a moderator effect on this relationship. The non-standardized coefficients for the male and female groups had very different values, equal to 0.307 ( $p$ value $<0.05)$ and $0.097\left(p 0.05>\right.$ value) respectively. For attractiveness, the $\Delta \chi^{2}$ had a value of 2.177, below the critical value of 3.841. The non-standardized coefficients for the male and female group had values equal to 0.157 ( $p$ value $<0.05$ ) and 0.285 ( $p$ value $<0.05$ ) respectively, indicating a difference. However, as discussed earlier, the $\Delta \chi^{2}$ does not support the moderator effect moderator for this relationship.

\section{Sports Involvement}

To confirm the validity of the scale, an Exploratory Factor Analysis (EFA) was conducted, using principal components technique. The extraction of factors was performed using a criterion of Eigenvalue $>1$, resulting in one-dimensional scale $(\mathrm{KMO}=0.933)$, with a total variance explained of $71.8 \%$, with all eight items possessing a factor loading greater than 0.80 . In sequence, the sample was divided into two subsamples (male and female). A new EFA was performed and the unidimensionality of the scale was again confirmed $(\mathrm{KMO}=0.927$ and 0.919 respectively), with a total variance explained of $72.7 \%$ and $67.2 \%$, respectively, and all eight items possessing factor loading greater than 0.77 . The scale's reliability coefficient (Cronbach's $\alpha$ ) was 0.94 . A scale having too many items (eight) can inflate Cronbach's $\alpha$ (HAIR et al., 2006), so the corrected item-total correlations were checked. They ranged from 0.753 to 0.828 and thus exceeded the suggested limit of 0.50 (BEARDEN; NETMEYER, 1999). The correlations between the items on the scale were measured using Spearman's rank correlation coefficient. They ranged from 0.582 to 0.796 . All were significant at the 0.01 confidence level but exceeded the suggested limit of 0.30 (BEARDEN; NETMEYER, 1999).

Following the procedure adopted by Shank and Beasley (1998), the sports-involvement score was operationalized as a variable sum. The average overall score was 40.1 (DP =11.99) and the median was 42. A binary variable was used to indicate the degree of sports-involvement. Thus, respondents who obtained scores of less than $42(\mathrm{~N}=499$, representing 48.7\%), were included in the low involvement group, where 157 were males and 342 were females. Respondents with scores 
greater than or equal to $42(\mathrm{~N}=526$, representing $51.3 \%)$ were included in the high involvement group, which was made up of 343 male and 183 female respondents.

\section{Hypotheses related to Sports-Involvement}

To test Hypothesis 3, the same sequence of procedures applied to test Hypothesis 2 was used. First, cross-validation and invariance tests were performed on the low (LSIG) and high sports-involvement group (HSIG). The analysis of the loose cross-validation showed that the GFI, CFI and RMSEA values suggested a good model fit for both groups, with values being equal to $0.972,0.995$ and 0.013 for the LSIG and $0.978,1.000$ and 0.000 for the HSIG respectively. Thus, the model provided a better fit for the HSIG than the LSIG. The LSIG had a significant $\chi^{2}$ (52.1 and $p$ value $>0.05$ ), as did the HSIG (41.6 and $p$ value $>0.05$ ). Therefore, no fit problems were identified, allowing us to accept the cross-validation criterion, since the measurement model appears valid for both samples. Then, the factorial structure equivalence was verified using Multiple Group Analysis. The GFI (0.975), CFI (1.000) and RMSEA (0.000) indicators demonstrate a good fit for the measurement model. The $\chi^{2}$ (93.8) indicator was significant ( $p$ value $>0.05$ ). Therefore, these results support the equivalence of the factorial structure, indicating that the structure of the measurement model is suitable for both groups, thus verifying the equivalence of the groups' factor loading. The results of the $\chi^{2}(106.2$ with $p$ value $=0.421)$, GFI (0.972), CFI (0.999) and RMSEA (0.005) support the equivalence of the loading factors, as well as the difference in $\chi^{2}$ between models $(12.5$ with $p$ value $=0.131)$. Thus the equivalence of the factor covariance was confirmed. However, the $\Delta \chi^{2}(48.4$ with $p$ value $<0.05)$ does not support the factor covariance equivalence between the groups. As there was no support for the factor covariance equivalence, the verification of the error variance equivalence could not be supported.

Since the equivalence of the factorial structure and loading factors was supported, we proceeded to test Hypothesis 3 using Multiple Group Analysis. When comparing the models, support was found for the existence of sport-involvement's moderator effect on the relationship between sports celebrity credibility and purchase intention. The $\Delta \chi^{2}$ for the model's fit was equal to 10.516 (104.266-93.750), greater than the critical value of the $\chi^{2}$ statistic for 3 degrees of freedom (7.815). In this way, the results provide empirical support for Hypothesis 3. Sports-involvement moderates the influence of endorser credibility on purchase intention.

The specific effect on each of the model's dimensions was tested. For expertise, the $\Delta \chi^{2}$ was equal to 0.488 , below the critical value for 1 degree of freedom (3.841). The non-standardized coefficients for the LSIG and the HSIG were equal to 0.213 ( $p$ value $<0.05$ ) and 0.161 ( $p$ value $<0.05$ ) respectively, indicating an obvious difference. However, as discussed earlier, the $\Delta \chi^{2}$ does not support the moderator effect for this relationship. For trustworthiness, the $\Delta \chi^{2}$ was equal to 0.117 , 
below the critical value of 3.841. The non-standardized coefficients for the LSIG and the HSIG were close, equal to $0.192(p$ value $<0.05)$ and 0.224 ( $p$ value $<0.05)$ respectively. However, for attractiveness, the $\Delta \chi^{2}$ was equal to 8.757 , above the critical value of 3.841 , thus providing support for the moderator effect specified in hypothesis H3c. It turns out that the standardized coefficients for the LSIG and the HSIG were very different, 0.240 ( $p$ value $<0.05)$ and 0.039 ( $p$ value $>0.05)$ respectively.

The summary of the study's hypotheses and results are presented on Table 4.

\section{DISCUSSION}

The results of this study provided empirical support for the hypothesized relationship between celebrity credibility and purchase intention. This result is consistent with the results found in Koo et al. (2012), Ohanian (1991) and Pornpitakpan (2003). All dimensions were shown to be significant to the relationship, albeit to varying degrees. This result differs from the results found in the original study of Ohanian (1991), which found support only for the relationship between endorser expertise and consumer purchase intention. Pornpitakpan (2003), in turn, found a positive relationship between each of the three dimensions and purchase intention. Additionally, he claims the empirical observation of each dimension's impact on purchase intention using the same scales for such a large sample prove that Ohanian's study may have had unusual results. In this way, the results of this study confirm the findings of Pornpitakpan (2003).

It was also noted that trustworthiness is the dimension of greatest influence on consumer purchase intention, followed by expertise. Attractiveness was the least influential. According to Pornpitakpan's (2003) results, expertise is the most influential factor on purchase intention, followed by trustworthiness and attractiveness. The strength of these two dimensions were very

Table 4. Proposed Hypotheses and Results

\begin{tabular}{|c|c|c|c|c|c|c|}
\hline Relations & Estimate (std) & $p$-value & Estimate (std) & $p$-value & \multicolumn{2}{|c|}{ Hypotheses } \\
\hline Purchase Intention & & & & & $\mathrm{H} 1$ & Supported \\
\hline PI $<--$ Attractiveness & $0.075(0.079)$ & 0.026 & & & H1a & Supported \\
\hline PI <-- Expertise & $0.206(0.193)$ & $* * *$ & & & $\mathrm{H} 1 \mathrm{~b}$ & Supported \\
\hline PI $<-$ - Trustworthiness & $0.259(0.196)$ & $* * *$ & & & $\mathrm{H} 1 \mathrm{c}$ & Supported \\
\hline Gender Moderation & Male & & Fema & & $\mathrm{H} 2$ & Supported \\
\hline PI $<--$ Attractiveness & $0.136(0.128)$ & 0.015 & $0.304(0.241)$ & $* * *$ & $\mathrm{H} 2 \mathrm{a}$ & Not supp \\
\hline PI <-- Expertise & $0.178(0.172)$ & 0.001 & $0.220(0.194)$ & $* * *$ & $\mathrm{H} 2 \mathrm{~b}$ & Not supp \\
\hline PI <-- Trustworthiness & $0.337(0.265)$ & $* * *$ & $0.064(0.045)$ & 0.408 & $\mathrm{H} 2 \mathrm{c}$ & Supported \\
\hline Involvement Moderation & Low & & High & & H3 & Supported \\
\hline PI $<--$ Attractiveness & $0.248(0.236)$ & $* * *$ & $0.031(0.035)$ & 0.499 & $\mathrm{H} 3 \mathrm{a}$ & Supported \\
\hline PI <-- Expertise & $0.200(0.193)$ & $* * *$ & $0.147(0.128)$ & 0.01 & $\mathrm{H} 3 \mathrm{~b}$ & Not supp \\
\hline PI <-- Trustworthiness & $0.140(0.106)$ & 0.058 & $0.279(0.203)$ & $* * *$ & $\mathrm{H} 3 \mathrm{c}$ & Not supp \\
\hline
\end{tabular}


similar, once again, corroborating the results of Pornpitakpan (2003). The findings of this study, however, contradict the results from the research of Cunningham, Fink and Kenix (2008), Liu, Chen and Minghua (2007) and Liu, Huang and Minghua (2007), which found that attractiveness has more influence than expertise.

The results of this study also provide empirical support for the hypothesized moderating effect of consumer gender, which was significant for trustworthiness, but non-significant for attractiveness and expertise. However, analyzing the effect of gender on attractiveness, there seems to be a subtle difference between groups: females, especially those with low sports-involvement, value celebrity attractiveness, while the same is not true for males, especially those with high sports-involvement.

This result is not in line with the results found by Saleem (2008), which did not identify differences between respondents of different genders in relation to purchase intention. The results of this study also contradict the findings of Ohanian (1991) and Petty, Cacioppo and Schumann (1983) that found no statistically significant evidence of differences between genders in relation to purchase intention. However, the results of this study corroborate the findings of Boyd and Shank (2004), who found differences in the assessment of sports celebrity credibility dimensions between genders.

Additionally, the results of this study provide empirical support for the moderating effect of Consumer Sports Involvement. This results is aligned with previous knowledge about sport sponsorship, since the phenomenon of fan involvement is known for being a good indicator for predicting sports-related behavior (SHANK; BEASLEY, 1998). The greater a person's sportsinvolvement, the greater the probability that he or she buys products endorsed by athletes (SHUART, 2007) or of the sponsoring firms of their favorite sports (LEVIN; BEASLEY; GILSON, 2008; MEENAGHAN, 2001). However, the moderating effect was shown to be significant for the attractiveness dimension, but not for expertise and trustworthiness.

When comparing the results obtained in the investigation of gender and sports-involvement's moderator effect, one can speculate that an interactive effect exists between gender and sportsinvolvement. Most of the respondents of the male gender have been classified as cases of high sports-involvement (68.6\%) and most of the female gender, as cases of low involvement (65.1\%). Attractiveness was the most influential dimension on the relationship between endorsement and purchase intention in the low sports-involvement group, as well as in the female group. Additionally, trustworthiness was the most influential dimension on the relationship between endorsement and purchase intention in the high sports-involvement group, as well as in the male group. Despite the large sample size used in this study $(\mathrm{N}=1,025)$, the test of the interactive effect between gender and sports-involvement would require a much greater quantity of subsamples than were available, what would make the ADF test unusable. This effect should therefore be tested for in future studies. 


\section{Managerial Implications}

The managerial contribution of this study is to provide tools that help make marketing decisions, since the investment in advertising activities, especially those linked to celebrity endorsements is typically high. Additionally, the study is intended to warn executives about the fact that demographic variables may impact the outcomes regarding celebrity endorsements. As the study has shown, while men are more influenced by the celebrity trustworthiness, women are more influenced by the attractiveness. So depending on the product category or customer base, athletes with different characteristics would be more adequate as an endorser. Two examples of this effect may be David Beckham, the retired soccer player, and Anna Kournikova, the retired tennis player. Both have never been amongst the top five players in their respective sports, but, due to their physical attractiveness, received an expressive amount of attention from the media, which resulted in huge endorsement contracts.

Marketing executives should also be aware that the consumer's level of sports-involvement with the celebrity's sport can moderate the strength of the endorsement on purchase intention. This is especially important depending on the type of product being endorsed. For example, a mass product would benefit more from an endorser of a more popular sport, i.e., a sport with a vast number of highly involved fans, then of a sport not so popular, if both athletes have similar images in terms of credibility.

Considering the source credibility dimensions, as the study's results highlight, it is imperative that the endorsed brand assess the athlete trustworthiness before establishing the endorsement agreement, as this was the most relevant dimension affecting the endorsed brand purchase intention. In addition, it is important to contractually anticipate possible misbehaviors of the athletes, since any action that may damage the athlete credibility may result in a negative impact on the endorsed brand as well.

\section{Limitations and Recommendations for Future Research}

The study used a non-probability sample, limiting the generalization possibilities (MALHOTRA, 2006). In addition, the decision to restrict the sample to undergraduate students from higher education institutions in Rio de Janeiro also introduces an important limitation to the generalizability of the results, as some specific characteristics of such a homogeneous group may have had implications on the assessment of different attributes. However, according to Yoo and Donthu (2000), students have effectively represented non-students and adults in many empirical studies.

Additionally, the research used scales that were not originally developed for the Brazilian context. Despite the thoroughness of the reverse translation, the careful pre-tests conducted, and 
the good validity and reliability indicators of the constructs measured, which provide confidence in the use of the scales, it should be noted that translation of the scales to the respondent's native language is unlikely to be perfect.

Lastly, the research design that used only a single male athlete as stimulus may have had some impact on the results, especially considering the results regarding the dimensions of source credibility. First, the use of only one athlete eliminates the possibility of comparison. Second, another limitation refers to the possible bias resulting of the use of a male athlete as research stimulus. Finally, as soccer is the most popular sport in Brazil, the choice of a soccer player may have had some impact on the results as well.

The present study indicates new research opportunities. Firstly, although Ohanian's (1991) model has been validated, the significance and strength of the dimensions are different than those found in the original study, even that they partially converge with results from other studies. In this way, new studies could explore this relationship. In addition, gender has received little attention in the literature and should be more deeply explored, including replicating the model tested by this study with other male and female celebrities, exploring how males and females respond to different stimuli in terms of purchase intention. Also, given that the study was based on a single athlete, it would be advisable to conduct further studies using other sports and athletes. Finally, it would interesting to study other product categories, specially investigating the possible interactions between the athletes used as stimuli, the product category investigated and other demographic variables, such as gender and age group.

\section{REFERENCES}

ABC NEWS. Top 10 Richest Soccer Players In The World 2015. ABC News. Retrieved 0601 , 2016, from http://www.abcnewspoint.com/top-10-richest-soccer-players-in-the-world-2015/

AMOS, Clinton; HOLMES, Gary; STRUTTON, David. Exploring the relationship between celebrity endorser effects and advertising effectiveness: A quantitative synthesis of effect size. International Journal of Advertising, v. 27, n. 2, p. 209-234, 2008.

ARAI, Akiko; KO, Yong Jae; ROSS, Stephen. Branding athletes: Exploration and conceptualization of athlete brand image. Sport Management Review, v. 17, n. 2, p. 97-106, 2014.

BEATON, Anthony A. et al. Sport involvement: A conceptual and empirical analysis. Sport management review, v. 14, n. 2, p. 126-140, 2011. doi: 10.1016/j.smr.2010.07.002

BENNETT, Gregg et al. The role of involvement in sports and sport spectatorship in sponsor's brand use: The case of Mountain Dew and action sports sponsorship. Sport Marketing Quarterly, v. 18, n. 1, p. 14, 2009.

BADENHAUSEN, K. Forbes, 11 jun. 2015. Disponível em Site da Forbes Magazine: <http:// www.forbes.com/sites/kurtbadenhausen/2014/06/11/the-worlds-highest-paid-athletes-2014behind-the-numbers/\#2732b7cb7fc4>. Acesso em: 02 mar. 2015. 
BOYD, Thomas C.; SHANK, Matthew D. Athletes as Product Endorsers: The Effect of Gender and Product Relatedness. Sport Marketing Quarterly, v. 13, n. 2, p. 82-93, 2004.

BUSH, Alan J.; MARTIN, Craig A.; BUSH, Victoria D. Sports celebrity influence on the behavioral intentions of generation Y. Journal of Advertising Research, v. 44, n. 01, p. 108-118, 2004. doi: $10.1017 / \mathrm{S} 0021849904040206$

CARLSON, Brad D. et al. Human brands in sport: Athlete brand personality and identification. Journal of Sport Management, v. 27, n. 3, p. 193-206, 2013.

CARNEIRO, Mariana. A utilização de celebridades e o múltiplo endosso na propaganda. 2002. Doctoral dissertation, Pontifícia Universidade Católica do Rio de Janeiro, PUC-Rio, Rio de Janeiro, Brazil.

CHOI, Sejung; RIFON, Nora J. Who is the celebrity in advertising? Understanding dimensions of celebrity images. The journal of popular Culture, v. 40, n. 2, p. 304-324, 2007. doi: 10.1111/j.15405931.2007.00380.x

CHUNG, Kevin YC; DERDENGER, Timothy P.; SRINIVASAN, Kannan. Economic value of celebrity endorsements: Tiger Woods' impact on sales of Nike golf balls. Marketing Science, v. 32, n. 2, p. 271-293, 2013. doi: 10.1287/mksc.1120.0760

CUNNINGHAM, George B.; FINK, Janet S.; KENIX, Linda Jean. Choosing an endorser for a women's sporting event: The interaction of attractiveness and expertise. Sex Roles, v. 58, n. 5-6, p. 371-378, 2008. doi: 10.1007/s11199-007-9340-z

DEES, Windy; BENNETT, Gregg; VILLEGAS, Jorge. Measuring the effectiveness of sponsorship of an elite intercollegiate football program. Sport Marketing Quarterly, v. 17, n. 2, p. 79-89, 2008.

ELBERSE, Anita; VERLEUN, Jeroen. The economic value of celebrity endorsements. Journal of Advertising Research, v. 52, n. 2, p. 149-165, 2012. doi: 10.2501/JAR-52-2-149-165

FINK, Janet S. et al. Female athlete endorsers: Determinants of effectiveness. Sport Management Review, v. 15, n. 1, p. 13-22, 2012. doi: 10.1016/j.smr.2011.01.003

FORBES. The World's Highest-Paid Athletes. Forbes, 2015. Disponível em Site da Forbes Magazine: $<$ http://www.forbes.com/athletes/list/\#tab:overall_header:endorsements_sortreverse:true $>$. Acesso em: 02 mar. 2015

FORBES. The World's Highest-Paid Athletes. Forbes. Retrieved 06 23, 2015, from http://www. forbes.com/athletes/list/\#tab:overall_header:endorsements_sortreverse:true

GARLAND, Ron; FERKINS, Lesley. Evaluating New Zealand sports stars as celebrity endorsers: intriguing results. In: ANZMAC 2003: a celebrations of Ehrenberg and Bass: marketing discoveries, knowledge and contribution, conference proceedings. University of South Australia, 2003. p. 122-129.

GOLDSMITH, Ronald E.; LAFFERTY, Barbara A.; NEWELL, Stephen J. The impact of corporate credibility and celebrity credibility on consumer reaction to advertisements and brands. Journal of advertising, v. 29, n. 3, p. 43-54, 2000. doi: 10.1080/00913367.2000.10673616

HAIR, J. et al. Multivariate Data Analisys. Nova Jersey: Prentice Hall, 2006.

PYUNG, Young; JAMES, Jeffrey D. Attitude toward advertising through sport: A theoretical framework. Sport Management Review, v. 14, n. 1, p. 33-41, 2011. doi: 10.1016/j.smr.2009.12.002 
KLINE, Rex B. Principles and practice of structural equation modeling. Guilford publications, 2015.

$\mathrm{KO}$, Yong Jae et al. The effects of sport involvement, sponsor awareness and corporate image on intention to purchase sponsors' products. International Journal of Sports Marketing and Sponsorship, v. 9, n. 2, p. 6-21, 2008.

KOO, Gi-Yong; RUIHLEY, Brody J.; DITTMORE, Stephen W. Impact of perceived on-field performance on sport celebrity source credibility. Sport Marketing Quarterly, v. 21, n. 3, p. 147$158,2012$.

LEE, Jeoung-Hak et al. The influence of service quality on satisfaction and intention: A gender segmentation strategy. Sport Management Review, v. 14, n. 1, p. 54-63, 2011. doi: 10.1016/j. smr.2010.02.002

LEE, Younghan; KOO, Jakeun. Athlete Endorsement, Attitudes, and Purchase Intention: The Interaction Effect Between Athlete Endorser-Product Congruence and Endorser Credibility. Journal of Sport Management, v. 29, n. 5, p. 523-538, 2015. doi:10.1123/jsm.2014-0195

LEVIN, Aron M.; BEASLEY, Fred; GILSON, Richard L. NASCAR fans' responses to current and former NASCAR sponsors: The effect of perceived group norms and fan identification. International Journal of Sports Marketing and Sponsorship, v. 9, n. 3, p. 35-46, 2008.

LIU, Matthew; HUANG, Yu-Ying; MINGHUA, Jiang. Relations among attractiveness of endorsers, match-up, and purchase intention in sport marketing in China. Journal of Consumer Marketing, v. 24 , n. 6 , p. 358-365, 2007. doi: 10.1108/07363760710822945

LIU, Matthew Tingchi; CHEN, Zhizhong; MINGHUA, Jiang. Influence of endorsers' attractiveness and product match-up toward purchase intention. International Journal of Business and Management, v. 2, n. 2, p. 3-12, 2007.

MALHOTRA, N. Marketing Research: An Applied Orientation. Prentice Hall, 2006.

MCCRACKEN, Grant. Who is the celebrity endorser? Cultural foundations of the endorsement process. Journal of consumer research, v. 16, n. 3, p. 310-321, 1989. doi: 10.1086/209217

MEENAGHAN, Tony. Understanding sponsorship effects. Psychology \& Marketing, v. 18, n. 2, p. 95-122, 2001. doi: 10.1002/1520-6793(200102)18:2<95::AID-MAR1001>3.0.CO;2-H

MELO NETO, Francisco Paulo de. Marketing esportivo. Rio de Janeiro: Record, v. 1, p. 995, 1995.

MEYERS-LEVY, Joan; MAHESWARAN, Durairaj. Exploring differences in males' and females' processing strategies. Journal of Consumer Research, p. 63-70, 1991. doi: 10.1086/209241

MILLER, Felicia M.; LACZNIAK, Gene R. The ethics of celebrity-athlete endorsement. What Happens When a Star Steps Out of Bounds?. Journal of Advertising Research, v. 51, n. 3, p. 499-510, 2011.

OHANIAN, Roobina. Construction and validation of a scale to measure celebrity endorsers' perceived expertise, trustworthiness, and attractiveness. Journal of advertising, v. 19, n. 3, p. 39-52, 1990. doi: 10.1080/00913367.1990.10673191

OHANIAN, Roobina. The impact of celebrity spokespersons' perceived image on consumers' intention to purchase. Journal of advertising Research, v. 31, n. 1, p. 46-54, 1991.

PETTY, Richard E.; CACIOPPO, John T.; SCHUMANN, David. Central and peripheral routes to advertising effectiveness: The moderating role of involvement. Journal of consumer research, $\mathrm{v}$. 10, n. 2, p. 135-146, 1983. doi: 10.1086/208954 
PORNPITAKPAN, Chanthika. The effect of celebrity endorsers' perceived credibility on product purchase intention: The case of Singaporeans. Journal of International Consumer Marketing, v. 16, n. 2, p. 55-74, 2004. doi: 10.1300/J046v16n02_04

ROWE, David; GILMOUR, Callum. Sport, media, and consumption in Asia: A merchandised milieu. American Behavioral Scientist, v. 53, n. 10, p. 1530-1548, 2010.

PWC. Changing the game: Outlook for the global sports market to 2015. PricewaterhouseCoopers. [S.1.], p. 40. 2011.

SALEEM, Farida. Impact of gender and age on single and multiple celebrities endorsements. Review of Business Research, v. 8, n. 3, p. p139-145, 2008.

SAUERBRONN, João FR; BARROS, Denise F. Mulheres Emocionadas-Perspectivas Sociais dos Antecedentes Emocionais e a Construção de Significados e Valores de Consumo Femininos de Esporte. Encontro Nacional dos Programas de Pós-graduação em Administração-ENANPAD, v. 29, 2005.

SCHIFFMAN, L., G., KANUK, L., L. Comportamento do Consumidor. Tradução Vicente Ambrósio. $6^{\mathrm{a}}$ ed. Rio de Janeiro: LTC, 1997.

SENO, Diana; LUKAS, Bryan A. The equity effect of product endorsement by celebrities: A conceptual framework from a co-branding perspective. European Journal of Marketing, v. 41, n. 1/2, p. 121-134, 2007. doi: 10.1108/03090560710718148

SHANK, Matthew; BEASLEY, Fred. Fan or fanatic: Refining a measure of sport involvement. Journal of sport behavior, v. 21, n. 4, p. 435-441, 1998.

SHUART, Joshua. Heroes in sport: assessing celebrity endorser effectiveness. International Journal of Sports Marketing and Sponsorship, v. 8, n. 2, p. 11-25, 2007.

SOLOMON, Michael R. Consumer Behaviour: Buying, Having, and Being. Prentice Hall, 2007.

SPRY, Amanda; PAPPU, Ravi; BETTINA CORNWELL, T. Celebrity endorsement, brand credibility and brand equity. European Journal of Marketing, v. 45, n. 6, p. 882-909, 2011. doi: $10.1108 / 03090561111119958$

TOTAL SPORTEK. Biggest Athlete Endorsement Deals In Sports History. Total Sportek. Retrieved 06 01, 2016, from http://www.totalsportek.com/money/biggest-endorsement-deals-sportshistory/

XING, Xiaoyan; CHALIP, Laurence. Effects of hosting a sport event on destination brand: A test of co-branding and match-up models. Sport Management Review, v. 9, n. 1, p. 49-78, 2006. doi: $10.1016 / \mathrm{S} 1441-3523(06) 70019-5$

YOO, Boonghee; DONTHU, Naveen; LEE, Sungho. An examination of selected marketing mix elements and brand equity. Journal of the academy of marketing science, v. 28, n. 2, p. 195-211, 2000. doi: 10.1177/0092070300282002

YU, Chia-Chen. Athlete endorsement in the international sports industry: a case study of David Beckham. International Journal of Sports Marketing and Sponsorship, v. 6, n. 3, p. 45-55, 2005. 